\title{
ПАРАДИГМА ЖЕНСКИЙ ПАСТОР В СЕГОДНЯШНЕЙ ЕВАНГЕЛИЧЕСКОЙ ЦЕРКВИ
}

\section{ОРИГИНАЛЬНАЯ СТАТЬЯ}

SÁ, Danielle Mendonça de ${ }^{1}$, GHEDINI, Robson Maurício²

SÁ, Danielle Mendonça de. GHEDINI, Robson Maurício. Парадигма женский пастор В сегодняшней евангелической церкви. Revista Científica Multidisciplinar Núcleo do Conhecimento. Год 06, эд. 12, Vol. 07, c. 159-173. Декабрь 2021 года. ISSN: 2448-0959, Ссылка доступа: https://www.nucleodoconhecimento.com.br/богословие-ru/парадигма-женскийпастор, DOI: 10.32749/nucleodoconhecimento.com.br/ru/104791

\section{СВОДКА}

В настоящее время существуют церкви, которые предпочитают ограничивать вклад женщин в осуществление своего служения в некоторых церковных секторах или даже заставлять ее молчать. Поэтому данное исследование основано на следующем вопросе: как анализ роли женщин в библейском контексте помогает в принятии легитимности женского пастырства в евангельской церкви сегодня? Таким образом, цель данного исследования состоит в том, чтобы обеспечить новый горизонт в понимании темы женского церковного лидерства, чтобы способствовать решению этой проблемы и разрушению парадигм, в свете Библия, описывая основные трудности, с которыми сталкиваются женщины в министерской деятельности, стремясь понять мысль, вытекающую из аспектов социального контекста, политические, исторические, экономические и религиозные с того времени, когда были

\footnotetext{
${ }^{1}$ Он имеет степень магистра богословия по направлению исследований «Перечитывание библейских текстов и контекстов» от FABAPAR, аспирант по аналитическим исследованиям Пятикнижия от FABAPAR, аспирант по библейскому богословию и толкованию от FABAPAR, степень бакалавра в Компьютерные науки от UNESA и степень бакалавра теологии в UNICESUMAR, близится к завершению. ORCID: https://orcid.org/0000-0003-0150-6313.

${ }^{2}$ Советник. ORCID: https://orcid.org/0000-0002-6862-8799
}

RC: 104791

Доступно в: https://www.nucleodoconhecimento.com.br/богословие-ru/парадигмаженский-пастор 
написаны библейские тексты. Для этого в качестве описательной методологической предпосылки использовались библиографические исследования и качественный подход, поскольку необходимо было представить элементы и фракты, извлеченные из истории относительно этих аспектов, поскольку совокупность всего позволяла перевести то, как вели себя, думали и чувствовали мужчины и женщины того времени. Также понятно, что эта мысль пронизывала традицию Церкви на протяжении веков, однако подчеркивается, что культурная традиция того времени не имеет таких же социокультурных элементов, как сегодня. В этом смысле собирается информация о трудностях, с которыми сталкиваются женщины в социальной и религиозной сфере, женской функции в иудаизме, их участии в христианстве, начиная с того, как Иисуса относился к ним; к их участию в Ранней Церкви, в дополнение к предоставлению пространства для анализа библейских текстов, проливающих свет на библейский взгляд на женское служение, рассказ об истории Девора, пастор на практике, хотя она не носит титула, а также, обращается к пастырскому служению как дару, данному Богом. Делается вывод, что сегодня она призвана к более бесстрашным, мужественным, верным Богу, благочестивым, послушным, преданным женщинам, пастырям душ, таким как Девора, Мариам, Олдане и другим. В конце концов, для мужчин и женщин есть один Бог, одна миссия (его), одно видение и одна цель, Иисуса.

Ключевые слова: Библия, церковь, лидерство, женщины, традиция.

\section{1. ВВЕДЕНИЕ}

Что касается женского лидерства в современном обществе, если бы следующий вопрос был адресован людям разного пола: «Вы бы охотно согласились на то, чтобы вас возглавлял военный капитан, если бы это был ваш подчиненный офицер? Согласитесь ли вы быть вторым пилотом самолета, зная, что его летает женщина? Согласитесь ли вы подчиниться руководящим принципам менеджера компании?» Возможно, ответ многих, как мужчин, так и женщин, будет таким: «Да, до тех пор, пока она полностью квалифицирована 
для этой роли». Однако в церковной среде рукоположение женщин на руководящие должности было предметом многих дискуссий в последнее время.

Церковная традиция часто запрещает женщинам предвещать или учить. Богословская основа этой теории основана на наставлениях, таких как павлины, которые происходят в контексте, в котором женщины, как правило, не обучались, в обществе, связанном с ценностями и обычаями, вытекающими из еврейской традиции, а также язычниками, где апостолу нужно было спасать и поддерживать порядок в Церкви, чтобы не возмущать новообращенных братьев в христианство. Еврейская традиция запрещала женщинам преподавать в синагоге. Греческая традиция почти полностью мешала им вести общественную жизнь, потому что они были далеки от мест и общественных мероприятий, в том числе религиозных.

На протяжении веков женская фригура страдала от интеллектуальных репрессий, пусть и молчаливых, а иногда и унижений, что спровоцировало женскую борьбу за свое место в мире, где целыми поколениями доминировала мужская фригура. Такие фракторы, как неравенство в оплате труда, невидимые препятствия на пути продвижения по службе, неуважение и злоупотребление мужской властью, по-прежнему являются реальностью для многих женщин сегодня. Столкнувшись с этой трудностью понимания, это исследование оправдано объединением библейских концепций и основ, которые обращаются к теме женского церковного лидерства, в конце концов, Бог не зависит от человеческих суждений для выполнения своей искупительной работы. В истории Церкви Иисуса полагается на мужчин и женщин как на соработников Своей Миссии, данной Церкви (BÍBLIA, 2011, 1 Coríntios 3.9).

С ростом числа христианских конфессий, которые признают легитимность женского пасторства и умножения церквей, основанных женщинами, произошло много столкновений между различными группами в евангельской среде. Тех, кто защищает и верит, что женщины могут занимать должности церковного пастырского руководства, и тех, кто защищает и верит, что только мужчины 
имеют божественное разрешение занимать такие должности. Есть контрапункт, который следует считать, что это имеет фундаментальное значение, знать, что Библия говорит об этом предмете. Поэтому мы стремились собрать информацию из библейской и иудео-христианской литературы по этому вопросу, чтобы прояснить следующий вопрос: как анализ роли женщин в библейском контексте помогает в принятии легитимности женского пастырства в евангельской церкви сегодня?

Библия - это непогрешимое и непогрешимое Слово Божье (BÍBLIA, 2011, 2 Timóteo 3.16). Учитывая, что люди, вдохновленные Богом, жили в социальном, политическом, историческом, экономическом и религиозном контексте, чтобы извлечь библейские истины, содержащиеся в них, важно знать культуру и оригинальное предложение библейских текстов, прежде чем выполнять их надлежащую интерпретацию, и, когда дело доходит до еврейской культуры, необходимо быть еще более осторожным из-за их литературных и поэтических особенностей, ибо, если бы элементы, строго связанные с культурой еврейского народа, сохранились в концептуализации текстов, такие ситуации, как использование женщинами чадры в качестве предпосылки в поклонении Богу, как написано апостолом Павлом в Bíblia Sagrada (2011) в 1 Коринфянам 11:1-16, в настоящее время испытывались бы.

Таким образом, это исследование направлено на то, чтобы внести свой вклад в прояснение того, что Библия учит о роли женщины в Церкви Христа и как Он делает ее участницей своей Миссии, с элементами и фрактами, извлеченными из истории, чтобы обеспечить новый горизонт в понимании темы женского церковного лидерства. Кроме того, он также призван способствовать решению этой проблемы в свете библейского взгляда на предмет, и для этого в качестве методологической предпосылки использовались библиографические исследования и качественный подход в описательном виде. При сборе информации для сбора данных и фактов, помимо Библия, это исследование имело следующих авторов: Curtis Allen, Branca Moreira Alves, Jacqueline Pitanguy, Simone Beauvoir, Russell Champlin, Arthur Cundall, Kathy Keller, Sandra RC: 104791

Доступно в: https://www.nucleodoconhecimento.com.br/богословие-ru/парадигмаженский-пастор 
Kochmann, Lucado, John MacArthur, Eugene Merril, Flávio Josefo, Charles Pfeiffer; Everett Harrison, Fani Averbuh Tesseler, Nicholas Thomas Wright между другими.

Эта статья применяется к женщинам, которые, как и автор, страдали от неприятия и предубеждений со стороны лидеров, которые не признают Божественную власть в осуществлении женского пастырского служения, а также ко всем тем, кто является сотрудником и любит Миссия Бога и Его Святое Слово. В его структуре изначально рассматривается тема под названием «подавленный голос в обществе», отчет об основных трудностях, с которыми сталкиваются женщины при получении доступа к образованию, и о том, как его видит общество в социальной и религиозной сфрере. В третьей теме собрана информация о «функция женщин в иудаизме» с учетом, в основном, мыслей раввина Sandra Kochmann по этому поводу.

Четвертая тема касается «участие женщин в христианстве», подразделяется на: «Иисуса нарушил человеческие парадигмы», в которой представлена информация о том, как Иисуса относился к религиозным авторитетам своего времени, которые отменили Закон Божий в ущерб человеческим традициям; «Иисуса ценил женщин», исходя из этой темы, объясняет, как Иисуса вел себя с женщинами того времени, ценил и включал их без всякого смысла, даже в нарушение раввинских традиций, таких как та, которая запрещала ему обращаться к ним публично; «женщины без речи в церкви», который анализирует и предлагает адекватную интерпретацию противоречивых библейских текстов, таких как 1 Тимофрею 2: 11,12 и 1 Коринфянам 14: 34,35, для правильного понимания предлагаемого послания; и последняя подтема, которая объединяет некоторые данные, относящиеся к «участие женщин в первобытной церкви» в библейском контексте.

В пятой теме рассказывается история «Дебора, пастор на практике», которая, несмотря на то, что не носила титул, обладала всеми присущими ему атрибутами, в основном призванием Бога, Который позволил ей руководить своим народом без это затмевает ее роль хорошей жены и матери, истинный 
пример для всех. Наконец, последняя тема обсуждения представляет «пастырское служение как дар, данный Богом», и, следовательно, он дает его, кому хочет и как хочет, без каких-либо различий, только для назидания своей Церкви; заканчивая заключительными соображениями.

\section{2. ПОДАВЛЕННЫЙ ГОЛОС В ОБЩЕСТВЕ}

Религиозное руководство на протяжении многих поколений принадлежало мужской фригуре. Для Раввина Kochmann[3] (2005) на протяжении всей истории предпочтение в изучении Библия было мужским, потому что женщины не имели доступа к такому количеству информации, как сегодня. О женской фригуре в 4 веке до н.э., в Древней Греции Ксенофонт провозглашает: «[...] Живите под пристальным наблюдением, смотрите как можно меньше вещей, слышите как можно меньше вещей, задавайте как можно меньше вопросов» (ALVES; PITANGUY, 1985, с. 12). Такие заявления отражали мышление того времени по этому вопросу и то, как женщины подавлялись обществом преимущественно мужского господства. В Бразилия только с конца 19 века женщины стали посещать школы, да и то робко, ведь изначально для женщин предназначались только частные школы (TESSELER, 2009).

Что касается того, как ее видят в обществе, Beauvoir (1970, стр. 72) утверждает в тексте, написанном в 70-х годах, что «мужчина определяется как человек, а женщина - как женщина. Когда она ведет себя как человек, ее обвиняют в подражании мужчине ». В более позднем тексте, содержащем свидетельство Кэти Келлер, жены одного из самых выдающихся пасторов сегодняшнего дня, Тим Келлер, за которого она вышла замуж и сопровождала его в руководстве West Hopewell Presbyterian Church в Вирджинии в течение девяти лет, она заявляет:

Em todos os lugares nos quais tenho ministrado desde então, sinto-me como uma mulher sem país. Em alguns deles, sou vista com suspeição, como uma 'louca feminista', porque encorajo mulheres a ensinar e a liderar, e eu mesma faço. Certa vez, no norte da Escócia, durante uma sessão de perguntas e respostas conduzidas pelo Tim após o culto de uma congregação da Free

RC: 104791

Доступно в: https://www.nucleodoconhecimento.com.br/богословие-ru/парадигмаженский-пастор 
Church of Scotland (Igreja Livre da Escócia), eu entrei na conversa. Como normalmente fazíamos a sessão de perguntas e respostas juntos todo domingo em nossa casa, após o culto da noite, nunca liguei sobre expressar minha opinião. No entanto, todas as cabeças viraram para me olhar com incredulidade estampada em face, masculina e feminina. Foi como se o cachorro de repente tivesse falado (KELLER, 2019, p. 8).

Проблема, с которой столкнулся Келлер в своих показаниях, к сожалению, до сих пор остается печальной реальностью многих женщин, будь то в социальной или религиозной среде. Согласно Perrot (1992, р. 185), «из истории часто исключаются женщины». По данным министерства экономики, 43,8 процента женщин занимают руководящие должности в Бразилия, то есть они попрежнему составляют меньшинство на более высоких должностях и, несмотря на то, что они занимают руководящие должности, их средняя заработная плата по-прежнему ниже, чем у мужчин, на уровне 69,8 процента, за те же должности в совете директоров, руководстве, надзоре, управлении, координации и управлении (BRASIL, 2019).

\section{3. ФУНКЦИЯ ЖЕНЩИН В ИУДАИЗМЕ}

Роль женщин в иудаизме, по словам Kochmann (2005), диверсифицировалась в соответствии с ее историческим социо контекстом и страдала от иностранного влияния, особенно греческого, что почти полностью мешало ей вести социальную жизнь, потому что это удерживало ее от мест и общественных мероприятий, в том числе религиозных. По ее словам,

Na época bíblica, as mulheres dos Patriarcas eram as Matriarcas, mulheres ouvidas, respeitadas e admiradas. Havia mulheres profetisas e juízas. As mulheres estavam presentes no Monte Sinai no momento em que Deus firmou o Seu Pacto com o povo de Israel. Participavam ativamente das celebrações religiosas e sociais, dos atos políticos. Atuavam no plano econômico. Tinham voz, tanto no campo privado como no público. Com o decorrer do tempo e por força das influências estrangeiras, especialmente a grega, foram excluídas de toda atividade pública e passaram a ficar relegadas ao lar. Essa situação das práticas cotidianas daquela época foi expressa nas leis judaicas então estabelecidas e permanece a mesma até hoje (KOCHMANN, 2005, p. 35-36).

RC: 104791

Доступно в: https://www.nucleodoconhecimento.com.br/богословие-ru/парадигмаженский-пастор 
В согласии MacArthur (2019) утверждает в своем отчете о женском положении во времена патриархов Библия, что

Os relatos bíblicos dos patriarcas sempre dão o destaque devido às suas mulheres. [...] Miriã, irmã de Moisés e de Arão, era tanto profetisa quanto compositora - e em Mq 6:4, o próprio Deus a honra, ao lado de seus irmãos, como uma das líderes da nação durante o Êxodo. Débora, também uma profetisa, era juíza em Israel antes da monarquia (Jz 4:4). [...] Em Provérbios, a sabedoria é personificada como uma mulher. A Igreja do Novo Testamento é igualmente representada por uma mulher, a noiva de Cristo (MACARTHUR, 2019, p. 16-17).

Однако языческая религия имела тенденцию обесценивать женщин. Греческая и римская мифология имела своих богов, таких как Диана и Афродита, обслуживаемых священными проститутками, практика, как сообщается, унизительная для женщин (MACARTHUR, 2019). Со временем некоторые элементы были включены в еврейскую традицию и собраны в Talmud, коллекции еврейских священных книг. Для Kochmann (2005, с. 37), «в талмудический период, между 3-м и 6-м веками Р.Ц.С., «Время, когда были установлены правила повседневной жизни евреев, основанные на интерпретации и анализе библейских текстов раввинами (исключительно мужчинами)», женщина сталкивается с препятствиями для посещения общественной сцены, потому что эта концепция «получает прямое влияние от древнегреческого общества, в которое она была вставлена. В нем у женщины практически не было общественной жизни, так как она находилась вдали от общественных мест и мероприятий, в том числе религиозных». По словам Джудит Баскин,

Carol Meyers argumenta que, quando o trabalho agrícola e a gravidez, duas esferas nas quais as mulheres desempenhavam um papel ativo, eram centrais na sociedade bíblica, a vida social e religiosa no Israel antigo era relativamente igualitária. Quando o estado político e a monarquia emergiram, e a vida religiosa foi institucionalizada no culto ao templo e na burocracia sacerdotal (a partir do século $X$ a.C), no entanto, as mulheres foram cada vez mais excluídas da arena pública e perderam o acesso à autoridade comunitária (BASKIN, 2020, s.p.).

RC: 104791

Доступно в: https://www.nucleodoconhecimento.com.br/богословие-ru/парадигмаженский-пастор 
В еврейскую культуру были введены определенные обычаи и привычки, которые считались столь унизительными и унизительными для женщин, о чем говорит Sandra Kochmann:

Começar cada dia escutando os homens dizerem 'Bendito sejas Tu, Eterno, nosso Deus, Rei do Universo que não me fizeste mulher' não é agradável para mulher alguma que, por sua vez, deve proferir com 'resignação' as palavras 'Bendito sejas Tu, Eterno, nosso Deus, Rei do Universo, que me fizeste segundo Tua vontade'. Essas bênçãos fazem parte da liturgia tradicional judaica dentro do conjunto de 'agradecimentos a Deus' conhecido como 'Bênçãos matinais' e que são recitadas toda manhã ao despertar. [...] Segundo o rabino contemporâneo Joel $\mathrm{H}$. Kahan, essa bênção se originou do dito helênico popular, citado por Platão e Sócrates [...]. 'Ser homem e não mulher' era central em ambas as culturas, onde a mulher ocupava um lugar secundário, especialmente na vida pública (KOCHMANN, 2005, p. 36-37).

Вышеупомянутый обряд был включен в еврейскую традицию, и женская фригура была уравновешена по отношению к мужской, классифицированной как «второсортное человеческое существо». Даже в еврейском обществе женщины и дети не учитывались в переписях, и это затрудняет определение их численности населения. Vaux (2004) утверждает, что даже самая низкая сумма 2 Царств 24.1-9 (BÍBLIA, 2011) очень преувеличена, потому что статистические документы отсутствуют, то есть, хотя в Библия есть некоторые числовые указания, они не сильно помогают.

Публичное чтение Тора является частью аспекта литургии поклонения в синагоге, от которой женщины будут освобождены. Если бы женщина встала на место мужчины, чтобы совершить чтение Тора, потому что она была включена в число читателей церемонии, во всех семи, это означало бы, что ни один из присутствующих мужчин не сможет выполнить такое обязательство, позорное положение, для многих евреев (KOCHMANN, 2005). Другие интерпретируют, что такое отношение будет считаться бесчестным только в тех случаях, когда чтение было полностью сделано женщиной (SHPERBER, 2003).

Kochmann (2005) утверждает, что, учитывая тот фракт, что в настоящее время еврейским женщинам уже разрешено принимать религиозные атрибуции, от 
которых они ранее были бы освобождены, как это также имеет место на других уровнях общества, многие из них заявили о праве учиться, чтобы сформировать раввинов и лидеров общин. Для нее знание предшествующих и мутаций еврейского закона помогло бы понять, насколько он динамичен и, следовательно, позволило бы лучше принять эту новую реальность.

\section{4. УЧАСТИЕ ЖЕНЩИН В ХРИСТИАНСТВЕ}

Bсе Священное Писание указывает на Иисуса, ибо Он является субъектом, целью и исполнением пророчеств Ветхого Завета (BÍBLIA, 2011, Mateus 1.22; 2.6,15,17-18,23; 3.3; 4.14-16). Согласно Келлер (2019, стр. 10), «Иисуса верил в вдохновение Ветхого Завета и обещал вдохновение Нового Завета» через Святого Духа (BÍBLIA, 2011, Јоão 14.26). Что касается правильной интерпретации библейских текстов, Allen (2012) утверждает, что необходимо интерпретировать их с уважением к контексту, в который они вставлены, и в свете Христа, исполнителя Библия во всей ее полноте, предполагая, что Он является образцом поведения для каждого христианина (BÍBLIA, 2011, 1 João 2.6), как сказал бы Sheldon (2007) в своей книге под названием Em seus passos o que faria Jesus? Поэтому необходимо проанализировать, что Он учит о роли женщины в ее Церкви и как Он также делает ее участницей своей миссии спасения и спасения человечества. Затем эта информация собирается кратко.

\section{1 ИИСУСА НАРУШИЛ ЧЕЛОВЕЧЕСКИЕ ПАРАДИГМЫ}

Во время земного служения Иисуса среди религиозных авторитетов того времени выделялась группа под названием «фарисеи», люди, которых евреи уважали как глубоко знающих еврейские законы (JOSEFO, 2004). Тем не менее, они построили свою собственную систему толкования, которая стала набором традиций и правил, часто ставящихся выше Священного Писания, когда между ними возникали разногласия, что становилось опасным, потому что они ценили человеческие традиции больше, чем Слово Божье, как предупреждал их Иисуса в Марка 7:13. Josefo (2004, стр. 819) классифицирует их как «[...] секту людей, 
которые хотят, чтобы мы судили их более образованными, чем другие, в религии, что они так дороги Богу, что Он сообщает им и дает им знание о грядущем» .

Согласно Allen (2012, стр. 54), в его комментарии к Матфея 12:1-8 «Иисуса прямо говорит о высокомерии фрарисейского толкования». Он обвинил их в том, что они не практикуют Божий Закон, хотя они были осведомлены об этом (BÍBLIA, 2011, Mateus 23.23-28). Для Merril (1987, стр. 412): «Иисуса, по сути, утверждал, что суд, наложенный на фарисеев, будет больше, чем тот, который пришелся на Ниневия. [...] фрарисеи не покаялись в проповеди того, кто был больше Йонас (Лк 11, 32)». Иисуса отверг набор наставлений, навязанных еврейской традицией, которые противоречили истинному Божественному замыслу спасения грешного человека (BÍBLIA, 2011, Mateus 18.11), среди них те, кто пытался помешать ему совершать чудеса в субботу, день покоя евреев, согласно Закону Божьему (BÍBLIA, 2011, Êxodo 34.21).

Вскоре после исцеления человека, у которого была одна из его деформированных рук в местной синагоге (BÍBLIA, 2011, Mateus 12:9-10), Иисуса отвечает фарисеям, которые спрашивали его о законности его поступка, говоря: «[...] Кто из вас будет человеком, у которого есть овца, если в субботу она упадет в яму, не ляжет на нее и поднимет ее? Да, насколько больше стоит человек, чем овца? Поэтому законно преуспевать по субботам» (BÍBLIA, 2011, Mateus 12.11-12), что означает, что практика добра должна быть ежедневной, независимо от дня недели. Иисуса есть Господь, «даже субботний» (BÍBLIA, 2011, Mateus 12.8). Он нарушил человеческие парадигмы и установил Царство Божье (BÍBLIA, 2011, Јоão14:6), согласно Своей доброй, совершенной и приятной воле (BÍBLIA, 2011, Romanos 12.2).

\section{2 ИИСУСА ЦЕНИЛ ЖЕНЩИН}

Как упоминалось выше, во время земного служения Иисуса женская фигура была недооценена обществом того времени. Однако Учитель не делал 
различий. Хотя он выбрал для себя двенадцать апостолов, апостольская коллегия состояла не только из них. У него также было много других учеников, среди которых были и женщины, «неизвестная практика среди раввинов своего времени» (BÍBLIA, 2011, стр. 1639), и некоторые из них помогали ему пожертвованием собственных фринансовых ресурсов (BÍBLIA, 2011, Lucas 8.1-3). Они играли фундаментальную поддержку и роль в служении Иисуса. Учитель поощрял их к ученичеству, даже повышая их важность до домашнего служения (BÍBLIA, 2011, Lucas 10:38-42). В рассказах об учениках Иисуса Библия больше цитирует о Мария Магдалина, Марфе, Мария, матери Иакова и Саломее, чем о Нафанаиле или Матфий. Кроме того, у Иисуса также было много анонимных учеников и возлюбленных сотрудников (BÍBLIA, 2011, Lucas 10.1), и сегодня Церковь Господа Иисуса разбросана по всему миру бесчисленными учениками (BÍBLIA, 2011, Mateus 28.18-20; Romanos 12.4-5).

Иисуса нарушил человеческие парадигмы, сославшись на самарянку в колодце Иакова (BÍBLIA, 2011, João 4.9), вопреки критике общества и даже непониманию ее собственных учеников (BÍBLIA, 2011, Јоão 4.27), а также превратил ее в миссионера своего народа (BÍBLIA, 2011, João 4.28-30). Согласно A Bíblia da Mulher: «В культурном отношении евреи и самаряне не общались друг с другом. Кроме того, считалось неуместным, чтобы раввин разговаривал с женщиной на публике. Поэтому отношение Христа к этой женщине было революционным». (BÍBLIA, 2011, р. 1639). Он с достоинством относился к женщинам, которые были маргинализированы обществом того времени (BÍBLIA, 2011, Mateus 9.2022; Lucas 7.37-50; João 4.7-27). Во время служения Иисуса женщины не только ценились, но и были уполномочены вместе с мужчинами быть «светом мира» (BÍBLIA, 2011, Mateus 5.14-16) и уполномочены Святым Духом свидетельствовать о Божьем спасении на краю земли (BÍBLIA, 2011, Atos 1.8).

MacArthur (2019, стр. 190) утверждает, что «Христос побуждал мужчин и женщин брать на себя свое иго и учиться у Него. Это также еще одно доказательство того, как женщины почитаются в Священном Писании». Они также были первыми, кто стал свидетелем Его воскресения и получил приказ RC: 104791

Доступно в: https://www.nucleodoconhecimento.com.br/богословие-ru/парадигмаженский-пастор 
поделиться с другими новостями о том, что Он жив (BÍBLIA, 2011, Marcos 16.7; João 20.15-18). Можно утверждать, что культурный поворот его времени, В Петре и в других учениках Иисуса, был преобладающим для них, чтобы усомниться в рассказе женщин, которые были свидетелями воскресения Иисуса (BÍBLIA, 2011, Marcos 16.9-11; Lucas 24.9-12), ибо, как упоминалось выше, согласно древней еврейской традиции, их публичное свидетельство было ненадежным.

Он также утверждает, что Мария Магдалина, ученица Иисуса, «становится одной из самых важных женщин в Новом Завете» (MACARTHUR, 2019, 183). Что касается ее прошлого, Евангелия описывают ее как женщину, которая была освобождена от одержимости демонами (BÍBLIA, 2011, Lucas 8.2; Marcos 16.9). Он утверждает, что «не раскрывая никаких унизительных подробностей прошлого этой женщины, они записывают ее рабство демонам, чтобы возвысить щедрую силу Христа» (MACARTHUR, 2019, стр. 190), то есть от рабыни демонов до верного последователя Иисуса Христа, она «стала частью внутреннего круга учеников, которые путешествовали с Иисусом в своих долгих путешествиях» (MACARTHUR, 2019, р. 189). По его словам, она тоже была одной из женщин, которые помогали Иисуса и его ученикам фринансовыми пожертвованиями. Согласно Lucado (2018, стр. 213): «После того, как Господь Иисуса исцелил Марию, она также стала преданной последовательницей. Ипполит Римский, богослов 3-го века, позже назовет его «Апостолом апостолов». Ее преданность даже заставила ее остаться в Иерусалиме во время распятия Иисуса (BÍBLIA, 2011, João 19.25).

В Евангелии от Иоанна 20:1-17 внимание привлекает отношение Мария. Увидев воскресение Иисуса, его реакцией, возможно, было твердое удержание Его, чтобы он не отпускал Его, до такой степени, что Он провозгласил в стихе 17: «Не останавливай Меня». Об этом выражении, Чамплин (1982, р. 636) утверждает, что «оригинальный греческий язык - «aptomai», [...] это слово может иметь значение обращения или сдерживания, указывая на нечто большее, чем простое прикосновение к какому-то объекту. [...] Мария RC: 104791

Доступно в: https://www.nucleodoconhecimento.com.br/богословие-ru/парадигмаженский-пастор 
Магдалина, вероятно, бросилась к ногам Господа Иисуса и вцепилась в них». Соответственно, MacArthur (2019, стр. 196) утверждает, что «Мария совершенно по-другому не хотела оставить Иисуса. Вот почему Иисуса даровал ему беспримерную честь, позволив ей быть первой, кто увидит и услышит его после его воскресения», такова была его преданность Ему. Она действительно признала его Сыном Божьим.

\section{3 ЖЕНЩИНЫ БЕЗ РЕЧИ В ЦЕРКВИ}

В 1 Тимофею 2:11,12 апостол Павел писал: «Женщина учится в тишине со всем подчинением. Я не позволяю женщине учить или иметь власть над мужчиной. Но молчи». Тем не менее, ясно видно, что, согласно Bíblia (2011), Богу не запрещает женщинам выступать на публике. По словам Кэти Келлер,

[...] há vários exemplos no Novo Testamento de mulheres sendo elogiadas, $\mathrm{e}$ não condenadas, por falarem em público. Mulheres profetizam em 1Coríntios 11:5 (observe que, em 1Coríntios 12:28, o dom de profecia é considerado superior ao dom de ensino); Priscila e Áquila explicam o evangelho a um homem (Apolo) em Atos 18:26 e, em Romanos 16:3, Paulo se refere à Priscila como uma 'colaboradora' (synergos), designação também aplicada à Evódia e Síntique em Filipenses 4:3, mulheres que participaram do trabalho de evangelismo ao lado de Paulo. Também há no Antigo Testamento exemplos de mulheres líderes e profetas, como Miriã, Débora e Hulda [...] (KELLER, 2019, p. 25-26).

Поэтому для Келлер (2019), в тексте, упомянутом выше, а также в тексте 1 Коринфянам 14:34,35, в котором говорится: «Женщины молчат в церквях, потому что им не позволено говорить; но подвластны, как того требует и закон. А если вы хотите чему-то научиться, спросите у своих мужей дома; потому что женщинам неприлично говорить в церкви», - Павел ссылается на порядок в богослужении, в преемственности с тем, к чему он говорил с главы 11, обучая, что мужчины и женщины должны выполнять свои роли, заповеданные Богом, и акт покрывания головы в поклонении Ему в 1 Коринфянам 11:1-16, культурный знак, связанный с женщинами. Она утверждает, что «Раннюю Церковь учили руководить своим богослужением в соответствии с моделью поклонения еврейской синагоги» (KELLER, 2019, стр. 28), однако для нее женщинам не

RC: 104791

Доступно в: https://www.nucleodoconhecimento.com.br/богословие-ru/парадигмаженский-пастор 
было запрещено публично использовать свои дары, поскольку апостол не осуждал бы это поведение, а скорее регулировал его.

Однако Champlin (1982) утверждает, что апостол Павел признавал абсолютный запрет женщинам участвовать каким-либо образом, активно и устно, в общественных службах, но, несмотря на это, такие запреты просто отражают отношение того времени, практику древнего еврейского обычая, применяемого в синагогах, ибо Новый Завет не был написан в вакууме. Поэтому естественно, что некоторые учения строго «местного и культурного» характера были включены, но они могут быть не обязательными для всех мест и времен.

Casos notáveis de mulheres crentes, que foram mestras, profetisas e elementos de autoridade, são chamados de 'atos extraordinários de Deus', por Calvino, o que não perturbaria a ordem normal da Igreja. Mas essa ordem 'normal', conforme ensinado neste texto, na realidade só se aplica bem ao antigo judaísmo, e não à igreja moderna, onde os preconceitos contra as mulheres tem desaparecido grandemente, e onde uma atitude mais realista é mantida (CHAMPLIN, 1982, p. 304).

Таким образом, запрет, выраженный в библейском тексте, не означает, что сегодня женщинам отказывают в административных должностях в евангельской церкви. Champlin (1982) считает, что как в тексте 1 Тимофею 2, так и в 1 Коринфрянам 14,34,35 возможно, что приказ, отданный женщинам, был направлен на поместную церковь, принимая во внимание конкретные ситуации, связанные с женщинами, которые позорили церковь и руководство, таким образом, не являясь нормативными для всех женщин Церкви Господа Иисуса. Он также считает, что в еврейской традиции порядочную женщину никогда не следует видеть на публике, за исключением некоторых особых праздников, что неудобно в сегодняшней евангелической церкви. Поэтому в этих социальных условиях было бы неуместно разрешать женщинам устно участвовать в государственных услугах. В еврейских синагогах эта процедура считалась бы скандалом. Однако такое наставление классифицируется им как культурный знак, как и вышеупомянутый, относящийся к использованию чадры женщинами в публичном богослужении, в 1 Coríntios 11.1-16 (BÍBLIA, 2011). Поэтому такая традиция не относится к нынешней Евангелической Церкви.

RC: 104791

Доступно в: https://www.nucleodoconhecimento.com.br/богословие-ru/парадигмаженский-пастор 
На указание, данное женщине, что она не учит мужчину, основываясь на порядке творения, выраженном в тексте Бытия 3:1-6, Russell Champlin утверждает, что

[...] Aquela primeira ocasião em que a mulher resolveu 'ensinar' ao homem, ou exercer influência sobre ele, foi horrivelmente fatal. [...] Por meio desse exemplo tornar-se-ia óbvio que a mulher não é digna de gozar de igualdade com o homem. Antes, a ordem natural das coisas é que a mulher sempre se ponha sob a autoridade masculina, pois isso evitará maiores desastres. Esse é o raciocínio por detrás desse versículo, o qual concorda perfeitamente com a atitude judaica acerca das mulheres. [...] Dessas maneiras é que vários intérpretes têm procurado subestimar o papel de Adão em toda a questão, fazendo Eva parecer muito pior do que realmente ela foi, o que é típico da mentalidade judaica. Os judeus chamavam Eva de 'mãe de toda a iniquidade e pecado' (Talmude Hieros. Sabbat. fol 5:2; Sohar em Gênesis, fol. 27:3) [...] (CHAMPLIN, 1982, p. 305).

В отношении текста 1 Тимофею 2.11,12 Bibliatodo (2020) учитывает тот фракт, что у Ефесской церкви были бы проблемы с лжеучителями и, поскольку еврейским женщинам было бы отказано в праве на обучение аналогично тому, что предлагалось мужчинам, они были бы не готовы решать эти вопросы, став легкими мишенями этих обманчивых мастеров, потому что они неспособны распознать истину. И он также комментирует, что

[...] Assim como Eva tinha sido enganada no jardim do Éden, assim as mulheres na igreja estavam sendo enganadas por falsos professores. $E$ assim como Adão foi o primeiro ser humano criado Por Deus, assim os homens na igreja de Éfeso seriam os primeiros em falar e ensinar, porque tinham mais experiência. [...] Outros eruditos, entretanto, sustentam que os róis que Paulo destaca são os intuitos de Deus para sua ordem criada (BIBLIATODO, 2020, s.p.).

Однако, подобно тому, как и Адам, и Ева обрели Божью праведность, они оба также испытали свою благодать (BÍBLIA, 2011, Romanos 5.18-19). Для Рассела Champlin,

O autor procura justificar suas regras severas e restringidoras acerca das mulheres à base do fato que é a ordem da criação [...]. Para o autor sagrado, a inferioridade de Eva, o fato que ela veio à existência depois de Adão, significa que todas as mulheres devem ocupar posição de inferioridade. Mas esse conceito foi abolido em Gl 3.28, pois Cristo é o fim de tudo isso (CHAMPLIN, 1982, p. 305).

RC: 104791

Доступно в: https://www.nucleodoconhecimento.com.br/богословие-ru/парадигмаженский-пастор 
С другой стороны, Wright (2020) утверждает, что Павел никогда не осуждал рукоположение женщин в пастырское служение. Для него фрокус как раз противоположный, что им не следует мешать учиться и учиться, так как это не означало бы, что они станут властными, как женщины-жрицы храма Арстаниды в Eqресе (ибо, по его словам, есть указания на то, что Тимофей был в этом городе, когда получил это письмо, направленное на него). Он утверждает, что в стихе 12 это то, что Павел отрицает, используя фразу «ни один из них не осуществляет власть человека»). Таким образом, для апостола женщин следует поощрять к изучению и обучению занимать руководящие должности, ибо Адам сознательно согрешил, он получил приказ непосредственно от Бога. Однако Ева была обманута. Поэтому женщин следует поощрять к учебе, чтобы не путаться.

Он утверждает, что материнство для апостола рассматривалось не как проклятие, как знак Божьего презрения, как многие евреи видели в то время, а как вклад в Божье творение. По его словам, автор библейского текста намеревался внести свой вклад в созидание Церкви Христовой, чтобы в единстве они могли служить Богу.

В интерпретации текстов, проанализированных выше, это исследование защищает теорию о том, что апостол Павел, хотя и был сторонником женского служения, должен быть разоблачен в следующей теме, из-за предоставленной модели поклонения напоминают иудейские синагоги и тот фракт, что поместные церкви, к которым он обращался в своих письмах, обладают: в его члене многие евреи, а также греки, обращенные в христианство, все еще очень укоренившиеся, в своих культурных традициях, он должен был быть энергичным и осторожным в своих действиях, связанных с ролью, которую играют женщины, с целью содействия порядку в богослужении и, особенно, единству Церкви, поскольку женское лидерство было бы предметом, который возмутил бы братьев, вновь обращенных в христианскую веру. что оправдывало бы такие запреты, как это было поддержано выше 
Champlin (1982). Однако, поскольку они происходят из культурного обычая, они не применимы к нынешней евангельской церкви.

Среди тех, кто выступает против женского пастырского рукоположения, некоторые говорят, что женщины, рукоположенные в пасторство, будут отчитываться перед Богом за выполнение своих служебных функций, которые, по их мнению, «несанкционированный Богом». Но разве это не противоречит Самому Богу, который упрекает, унижает и даже душит служение женщины, избранной Им для осуществления пастырского служения, с атрибутами, которые квалифицируют еe, что включает в себя неблагородного представителя перед Богом и мужчинами? (BÍBLIA, 2011, 1 Timóteo 2.15). Другими словами, это как если бы Бог избрал и наделил женщину пастырством, и это, основываясь на элементах культурной традиции, как упоминалось выше, сказало: «Я не могу принять, потому что это ситуация, которая противоречит социально-экономической и религиозной традиции того времени, когда были написаны библейские тексты».

Как будто Церковь снова пережила ситуацию, подобную ситуации апостола Петра в Деяния 10, когда Бог сказал ему: «Не делай вас общим для того, что Бог очистил» (BÍBLIA, 2011, Atos 10.15), ссылаясь на евангелизацию язычников, но представляя в видении животных, считающихся нечистыми для евреев, согласно Закону Божьему, в Левит 11. Хотя в разных контекстах понимание также применимо к теме, потому что апостол несколько раз настаивает на своем убеждении, основанном на человеческих традициях, выступая против Божьей воли достичь языческого народа, но через Откровение Бога он признает, что Иисуса Христоса умер за всех, без каких-либо различий (BÍBLIA, 2011, Gálatas 3.28), а затем провозглашает: « [...] Я признаю, по истине, что Бог не любит людей». (BÍBLIA, 2011, Atos 10.34). Точно так же не следует пытаться ограничить действие Бога, навязывая ему элементы, характерные для человеческих традиций. 
Как и в библейские времена, Бог избрал женщин, одетых Святым Духом, способных вести и пасти жизнь для Его Царства, которое, несмотря на то, что идет вразрез с социокультурным контекстом того времени, когда были написаны библейские тексты, не имеет подобных аспектов сегодня. Для Бога важно, чтобы Его дети служили Ему в послушании, вере и любви, прислушиваясь к призванию Служения, которое Он даровал им. Как и упомянутые выше фарисеи, воля и Божественное избрание вызываются под контроль из-за мировоззрения тех, кто настойчиво решает применить к христианской действительности элементы, характерные для местной культуры. Вопреки традиции того времени, Иисуса ценил женщин, позволял им учиться и быть соучастниками Божьей Миссии, как и мужчины.

\section{4 УЧАСТИЕ ЖЕНЩИН В ПЕРВОБЫТНОЙ ЦЕРКВИ}

Женщины принимают активное участие в библейском контексте. В создании церкви Филипп участвовали женщины (такие как Лидия, в Atos 16.11-15, 40 (BÍBLIA, 2011)), и они также участвовали в провозглашении Евангелия в Верии (БИБЛИЯ, 2011, Деяния 17:12), и вместе с мужчинами им было поручено провозглашать благую весть о Божьем спасении (BÍBLIA, 2011, Mateus 28.1820), чтобы служить Бог и учить человечество его посланию (БИБЛИЯ, 2011, Законы 18.24-26; Римлянам 16:1-7). Ранняя Церковь собиралась в домах (BÍBLIA, 2011, Atos 18.24-26; Romanos 16.1-7), и женщины активно сотрудничали с ученичеством. Была ли церковь, которая собиралась в домах, «менее церковной»? Tupan Júnior (2017, стр. 18) утверждает, что «Церковь это не структура, это не храм, это не институт, но это люди, обращенные к Господу Иисуса». Для Champlin (1982, стр. 160) «большинство христианских общин апостольской эпохи собирались в домах, вероятно, по фринансовым причинам».

Как упоминалось выше, Павел приветствует Нимфу и церковь в своем доме (BÍBLIA, 2011, Colossenses 4.15). Он никогда не цитирует, например, «священнику» или «апостолу», который находится в доме Нимфы, но относится

RC: 104791

Доступно в: https://www.nucleodoconhecimento.com.br/богословие-ru/парадигмаженский-пастор 
непосредственно к ней, так что не исключено, что она сама была руководителем церкви, собравшейся в ее доме. В своем приветствии римлянам он цитирует:

Recomendo-Ihes nossa irmã Febe, serva da igreja em Cencréia. Peço que a recebam no Senhor, de maneira digna dos santos, [...] pois tem sido de grande auxílio para muita gente, inclusive para mim. Saúdem Priscila e Áquila, meus colaboradores em Cristo Jesus. [...] Saúdem também a igreja que se reúne na casa deles. [...] Saúdem Maria, que trabalhou arduamente por vocês (BÍBLIA, 2011, Rm 16.1-7).

Можно заметить, что в разное время апостол обращается к словам, дополняющим осуществление женского служения. В других, таких как 1 Тимофрею 2, проанализированных выше, по словам Champlin (1982), апостол должен был быть жестким, чтобы сохранить порядок в богослужении, не скандализируя еврейских и языческих братьев, обращенных в христианство, многие из которых все еще укоренились в своих культурных традициях. Так в какой же момент Священное Писание утверждает, что женщины не должны осуществлять пастырское служение и получать рукоположение, то есть «признание дара»? Вовсе нет. Хотя апостол Павел, вдохновленный Богом, сравнивает любовь мужа к своей жене с любовью Христа к своей Церкви (BÍBLIA, 2011, Efésios 5.25-26) и делает то же самое в отношении подчинения: «Вы, женщины, подчиняетесь своему, как Господу; ибо муж есть глава женщины, как и Христос есть и глава Церкви, будучи сам спасителем тела» (BÍBLIA, 2011, Efésios 5.22-23), церковное руководство женщиной не запутывает и не изменяет ее роль матери и жены и подчинение. Господство мужа над женой является библейским (BÍBLIA, 2011, Gênesis 3.16), но доминирование всего мужского класса над женским классом, то есть всех мужчин в обществе для всех женщин, является культурным признаком, как упоминалось выше.

Библия цитирует женщину, которая была призвана Богом пасти целый народ. Она была лидером, но она была женой Лапидофова, она судила дело народа, но она была женой Лапидофова, она была служителем Слова, но она была женой Лапидофова, она была женой Лапидофова, но она была женой 
Лапидофова. Библия никогда не представляет Лапидофова как лидера или с какой-либо атрибуцией, которой он мог бы обладать. Она упоминает только, что эта женщина, избранная самим Богом вождем, была женой Лапидофова. Согласно Cundall (1986, р. 81), «Ничего не известно о Лапидофрова, муже Девора, за исключением простого упоминания его имени, которое было не единственным, которое было стерто, поскольку сам Барак играл второстепенную роль в борьбе. Он получил мужество и вдохновение за присутствие этой великой и талантливой женщины». Девора была правительственным, военным и духовным лидером своего народа (BÍBLIA, 2011, Juízes 4.4,5), но была отсылкой хорошей матери и хорошей жены к «неизвестной» Лапидофова.

Когда Бог избирает на служение, Он также наделяет силой. Когда он это делает, он тоже учит, он учит. Именно Он научил Девора иметь все эти руководящие и правительственные задания и продолжать быть хорошей женой и хорошей матерью, вплоть до того, что она стала ориентиром для всего народа (BÍBLIA, 2011, Juízes 5.7). Сам Бог поместил правильные слова в нужное время и в правильной мере на уста Девора, и все, что ей нужно сделать, это повиноваться Ему и продолжать быть лидером Израиль и женой Лапидофова (BÍBLIA, 2011, Juízes 4-5).

\section{5. ДЕБОРА, ПАСТОР НА ПРАКТИКЕ}

Девора была лидером народа Израиль, который жил во времена, когда люди пренебрегали Бог. Кальвин признал лидерство и правительство Девора и приписал то, что он назвал «Чрезвычайными деяниями, совершенными Бог» (CHAMPLIN 1982), 304). Правителями того времени были судьи (MERRIL, 1987). Эти судьи, под действием и правлением самого Бога, совершали героические поступки на благо народа. Бог учредил судей для управления Своим народом, ибо «под руководством Иисус Навин была начальная фаза завоевания земли. Земля была разделена между коленами, но израильтянам было необходимо оккупировать предназначаемую для них территорию» (PFEIFFER; HARRISON,

RC: 104791

Доступно в: https://www.nucleodoconhecimento.com.br/богословие-ru/парадигмаженский-пастор 
1985, р. 42). Цари появились до тех пор, пока годы спустя, первым из них был Саул (BÍBLIA, 2011, 1 Samuel 8).

Во времена судей не было Царя над народом, но Бог создал их, чтобы они вели их, судили дело Израиль и вели их, следуя руководству Моисей и Иисус Навин. Поэтому Девора, будучи судьей в Израиль, была также правительницей этого народа, как гражданского (судил дело народа, Juízes 4.4 (BÍBLIA, 2011)), так и военного (он дал военные стратегии, Juízes 4.6-7 (BÍBLIA, 2011)), так и духовного (он получил руководство Бог и делегировал свои приказы народу Израиль, Juízes 4.4-7 (BÍBLIA, 2011)). Божественная цель заключалась в том, чтобы назначить Девора руководить своим народом, что было функцией крайней ответственности и власти, в то время как он страдал от угнетения Джабима, царя Ханаана. Эти хаотические условия существовали потому, что Израиль принял новых богов и поэтому переживал Божественный суд. Тогда Бог воскресил Девора, которая собрала людей из всех племен и добилась могучей победы в Кисоме и Zaananim» (MERRIL, 1987, 170).

Был и другой решающий и изначальный аспект, он был доступен и, с верой в Бога и мужеством, повиновался Его призванию (BÍBLIA, 2011, Juízes 5.7). Merril (1987, р. 170) утверждает, что «после триумфа Девора земля отдыхала в течение сорока лет». Вдохновленная Богом, она представила Бараку стратегии войны и призвала их к бою: «Барак и остальные израильтяне, пораженные множеством врагов, попытались уйти и уйти [...]. Но Девора остановила их и повелела сражаться в тот же день без страха, ибо победа зависит от Бога, и они должны уповать на Его помощь» (JOSEFO, 2004, стр. 227).

Первоначальная трусость Варак в руководстве армией в трудном положении нации и смелость и бесстрашие Девора в руководстве целым народом показывают, что Бог действует в жизни того слуги или слуги, который предоставляет себя в свое полное распоряжение, независимо от его пола (позже Девора споет эту пророческую песню: «Тогда [...] Господь властвовал надо мной над доблестными» (BíBLIA, 2011, Juízes 5:13), имея в виду 
доблестных военных, в печально известном участии в качестве лидера, вместе с Варак). Cundall (1986, р. 23) утверждает, что они разделяли лидерство нации: «[...] Девора с Бараком в качестве поддержки (Jz 4:5), [...]». Тем не менее, в Послании к Евреям 11:35 (BÍBLIA, 2011) она не упоминается, только Барак, мужская фригура, несмотря на доказанное лидерство, осуществляемое с гражданской и духовной властью, дарованной Богом, честью, известностью и мужеством. Возможное объяснение основано на преобладающей культуре того времени, которая дисквалифицировала женщину от занятия таких должностей, о чем говорилось выше.

Более того, вполне понятно, что, хотя у Девора были все атрибуты «пастушки», текст явно не представляет ее как таковую, а скорее как судью и пророчества, поэтому идея «пастухи», связанная с поведением людей, была упомянута только позже в Книгах Иезекииля и Иеремии (BÍBLIA, 2011, Ezequiel 34; Jeremias 3.15-17). Ранее он ассоциировался исключительно с Бог (BÍBLIA, 2011, Gênesis 49.24; Salmo 23.1). Таким образом, возможность автора Книги Судей отбрасывается, ссылаясь на нее как на таковую, хотя в ней представлены все характеристики пастушки, рукоположенной Богом. Наиболее близким к этому слову в Ветхом Завете, учитывая его атрибуцию, был термин «священник».

Согласно Cundall (1986, р. 18), «первосвященник, в силу своего положения в центральном святилище, мог считаться судьей, поскольку святилище было традиционным местом для разрешения споров, а также было местом, где искали получить Божье благословение перед военным походом». Однако это занятие имело дурную славу в то время из-за неготовности и несерьезности священников того времени (BÍBLIA, 2011, Juízes 17-18). Но посреди греха и идолопоклонства Девора осталась верна Богу и Торе. Мудрая и богообразная женщина, многие толпились вокруг нее, чтобы посоветовать и попросить ее о помощи. Затем она судила под пальмой, на открытом воздухе, то есть там, где каждый мог слышать и наблюдать за ней, и предупреждала их, чтобы они покаялись в грехах (BÍBLIA, 2011, Juízes 4.5). 
Согласно Cundall (1986), Барак сам признавал видное правительство и руководство в Девора. Таким образом, хотя она была квалифицирована как «судья» и «пророческая», ее отношение было истинным «пастушкой» Божьего стада, и это видно по тому, как она передала божественное Послание спасения народу Израиля, в пророческом характере еe служения, в духовной проницательности, в чувствительности к Божьему голосу, в еe позиции лидерства и целостности, которые были столь благородными и вдохновляющими, до такой степени, что ее считают «матерью всего Израиля» (BÍBLIA, 2011, Juízes 4,5), с несомненно образцовым поведением.

\section{6. ПАСТЫРСКОЕ СЛУЖЕНИЕ КАК ДАР, ДАННЫЙ БОГОМ}

Апостол Петра в 1 Петра 4:10-11, вдохновленный Богом, написал Церкви Христовой наставление, что каждый должен исполнять полученный им дар, как добрые мыслители многообразной Благодати Божьей. Он упоминает следующие духовные дары: «дары речи («если кто-то говорит»)», которые включают в себя «апостольство, пророчество, различение духов, учение, евангелизацию и увещевание» и «дары служения («если кто-то управляет»)», которые состоят из «лидерства, веры, управления, помощи и безбрачия» (BÍBLIA, 2011, p. 1979-1980). В библейском тексте, приведенном выше, он наставляет, что каждый христианин должен применять свои духовные дары для служения другим, для созидания церкви и для прославления Бога. В его заявлении нет различий между полом, мужчиной и женщиной, расой и социальным классом, поскольку он признает, что Бог не имеет смысла распространять свои духовные дары. MacArthur (2019, стр. 15) утверждает, что «с первой главы Библия нас учили, что женщины, как и мужчина, несут печать собственного образа Божьего (Бытие 1:27; 5:1-2)», то есть Бог желает относиться одинаково ко всем.

В 1 Коринфянам 12:7 апостол Павел говорит, что «проявление Духа дано для того, что полезно». Это означает, что именно Бог выбирает, назначает и квалифицирует христианина на служение в Теле Христовом, без какого-либо

RC: 104791

Доступно в: https://www.nucleodoconhecimento.com.br/богословие-ru/парадигмаженский-пастор 
различия, для созидания Церкви Христовой, роста, зрелости и единства, поскольку зрелая церковь не управляется каждым «ветром» доктрины (BIBLE, 2011, Ефресянам 4:12-13). О термине «пастырь», от греческого «роimén», согласно A Bíblia da Mulher,

Davi é apresentado como um pastor cuidando do rebanho de seu pai. No mundo antigo o termo "pastor" costumava ser usado como metáfora para governante. Tanto no Antigo Testamento quanto no Novo Testamento, o povo de Deus é descrito, por analogia, como um rebanho, enquanto os representantes de Deus são chamados de pastores (2Sm 5.2; 7.7-8; SI 23.1; 78.71-72; Ez 34.1-31; Jo 10.1-18). [...] A imagem de pastor/rebanho é associada repetidamente a Davi e a Jesus (SI 23, 1Sm 17.15, 20, 28, 34, 40; 2Sm 5.2; 7.8; Ez 34.23) (BÍBLIA, 2011, p. 488).

Хотя в библейском тексте упоминается ответственность земных пастырей в заботе об «овцах» (BÍBLIA, 2011, Hebreus 13.17), важно отметить, что они не являются и никогда не будут от него, но от Иисуса, как Он Сам заявил Петра, призывая его пасти своих «овцах» (BÍBLIA, 2011, João 21.16-17), поэтому правительство, верховенство и власть принадлежат только Богу. Он назначает их сотрудниками своей Миссии (BÍBLIA, 2011, 1 Coríntios 3.9, Mateus 16.18), в конце концов, Христос является главой Церкви (BÍBLIA, 2011, Efésios 4.15) и использует тех, кто хочет, как мужчину или женщину (BÍBLIA, 2011, 1 Coríntios 12.6-14).

Как упоминалось выше, следуя четкому понятию термина «рукоположение», «признать дар», отрицать это признание дара, дарованного кому-то самим Богом, означало бы сопротивляться Божьей воле (BÍBLIA, 2011, Atos 11.17-18). Поскольку пастырское служение также понимается как дар, данный Святым Духом Церкви Христовой, можно показать, что Бог через Святого Духа может даровать его как мужчинам, так и женщинам за то, что полезно для Него (BÍBLIA, 2011, 1 Coríntios 12.7). Также в 1 Петра 4:11 «слово «осознает» происходит от греческого глагола energeo, что означает трудиться,работать, производить, производить, осуществлять» (CHAMPLIN, 1982, стр. 193), то есть Бог суверенен и всеведущ и не означает людей, но притягивает всех, спасает 
всех, кто верит в Него, Своей благодатью и любовью (BÍBLIA, 2011, João 3.1618), и наделяет тех, кого он хочет, производить то, что ему нравится.

Апостол Павел, описывая христиан как соработников Христа, говорит: «Чем мы обладаем, чего не получили от Бога? «Ибо кто заставляет тебя выходить? И что у вас есть то, что вы не получили его, и если вы получили его, почему вы хвастаетесь, как будто вы не получили его?» (BÍBLIA, 2011, 1 Coríntios 4.7), потому что были некоторые, кто хвастался, как будто они были носителями Славы, которая от Бога. В этой связи Champlin (1982, стр. 157) утверждает, что даже сегодня «некоторые действуют так, как будто то, что было произведено ими». Пережив интенсивный опыт общения с Богом, Иов сказал: «Я знаю, что вы можете сделать все и что ни один из ваших планов не может быть остановлен» (BÍBLIA, 2011, Jó 42.2). Поэтому, если все принадлежит Богу и во славу Его Славы, Он Сам распределяет Свои дары на благо Своего спасительного труда. Согласно A Bíblia da Mulher, «духовные дары [...] дарованы Богом не для того, чтобы возвеличить человека, у которого они есть, а для увеличения его усилий в служении. Подарки вручаются женщинам и мужчинам, но без требования, чтобы все дары принадлежали любому полу.» (BÍBLIA, 2011, р. 1802), что подтверждает, что Бог не делает различий в распределении Своих даров.

Lima и Mello (2016) показывают в своих исследованиях, что есть случаи, когда есть признание дара Божьего, дарованного женщинам, но отказ ей в титуле, что, по крайней мере, непоследовательно. Есть те, кто предпочитает называть их «миссионерами» или даже «врачами», но не «пасторами», хотя у них есть все качества для осуществления пастырского служения, включая, самое главное, призыв Божий. С другой стороны, есть также много людей, которые носят этот титул, никогда не отдаваясь пасторству, многие из них, к сожалению, служат насмешкой над Евангелием. В интервью журналу Seara (который пришел на смену журналу «А Seara»), Nascimento (1998, стр. 17), он утверждает: «[...] Хотя в церкви был достигнут большой прогресс в отношении женской работы, предрассудки все еще существуют, особенно в иерархической RC: 104791

Доступно в: https://www.nucleodoconhecimento.com.br/богословие-ru/парадигмаженский-пастор 
сорере. Женщина, даже лидер, не имеет того значения, которое имеет священник». В любом случае, важно отметить, что каждый христианин является слугой Христа и «Без сознания тайн Божьих» (BÍBLIA, 2011, 1 Coríntios 4.1), поэтому Слава, власть и владычество являются и всегда будут исключительно От Бога.

\section{7. ОКОНЧАТЕЛЬНЫЕ СООБРАЖЕНИЯ}

По элементам и фактам, приведенным в исследовании, можно сделать вывод, что, главным образом, благодаря влиянию еврейской культуры и традиций, а также других народов, со времени написания библейских текстов преобладание лидерства в Библия было мужским. Однако женщинам, облеченным Святым Духом, освященным и избранным Богом, никогда не мешали выполнять служебные и руководящие фрунцции, а также осуществлять духовные дары, которые Он даровал. Можно видеть, что господство мужа над женой является библейским (BÍBLIA, 2011, Gênesis 3.16), но доминирование всего мужского класса над женским классом, то есть всех мужчин в обществе для всех женщин, является культурным знаком. Таким образом, по фундаментальному вопросу в отношении церковного лидерства со стороны женщин, эта статья показывает, что анализ роли женщин в библейском контексте, по сути, помогает в принятии легитимности женского пастырства в евангельской церкви сегодня, поскольку было бы неуместно обязаны этими многочисленными библейскими свидетельствами, во имя церковных традиций, отказывать женщинам в должной и библейской свободе самовыражения при исполнении ими своих служебных обязанностей, дарованных Самим Богом.

Однако сегодня все еще есть много людей, которые с их заранее сорормированными идеями не могут представить или ассимилировать то, что кажется им противоположным, и этим, что касается женщин, они пытаются заглушить свои голоса, удерживая их занимать позиции церковного руководства, даже если с рвением, властью, смелостью, верой и любовью, дарованными Богом. Многие богобоязненные женщины, добродетельные,

RC: 104791

Доступно в: https://www.nucleodoconhecimento.com.br/богословие-ru/парадигмаженский-пастор 
благочестивые, послушные, слуги Всевышнего, исполненные Святого Духа, преданные изучению Священного Писания, молитве и пастырству душ и которые также убеждены в том, что их служение призвание находится на стороне Бога, были отвергнуты и даже унижены в своем служении, ибо многие выступают против женского присутствия на кафедрах церквей в роли проповедников Евангелия или пастырей стада Христова, ибо считают небиблейской и недопустимой идею подчинения авторитету женщиныруководителя, даже при отсутствии библейского авторитета для установления этих правил, как упоминается в исследовании.

Тем не менее, важно знать, что ученики Христа являются только соработниками Божьей Миссии (BÍBLIA, 2011, 1 Coríntios 3.9) и что именно Он обладает всей властью (BÍBLIA, 2011, Efésios 4.15), чтобы использовать тех, кто хочет, как Он хочет, согласно Его воле (BÍBLIA, 2011, 1 Coríntios 12.11), для строительства Его Церкви. Исследования показывают, что Бог наделил силой и одобрил лидерство Девора над Своим народом, не для того, чтобы дать «урок» мужчинам, которые пренебрегали его призванием в то время, а скорее для того, чтобы еще раз доказать, что Он суверенен и что Он распространяет Свои духовные дары тем, кто хочет, будь то мужчина или женщина (BÍBLIA, 2011, Efésios 4.12-15; 1 Coríntios 12.6-14). Поэтому вместо того, чтобы цепляться за элементы социокультурного контекста, в котором жила Церковь в то время, когда писались библейские тексты, каждый христианин может расти и укрепляться в Боге как неотъемлемой части Церкви Всевышнего.

Таким образом, сегодня все больше верующих людей, воинов, мужественных, благочестивых, пастырей душ и послушных Богу, таких как Павел, Петра и многие другие, призваны сегодня. Для более бесстрашных, мужественных, верных Богу, благочестивых, послушных, верных, душевных пасторов, таких как Девора, Мариам, Олдане и многих других по сей день. Что Божий замысел в воспитании сослуживцев для Его миссии в Церкви (BÍBLIA, 2011, Efésios 4.1112) может быть выполнен, и Его Церковь построена, оживлена и укреплена для Его Славы, в конце концов, именно для этой цели человечество было создано RC: 104791

Доступно в: https://www.nucleodoconhecimento.com.br/богословие-ru/парадигмаженский-пастор 
Им, мужчиной и женщиной, как для одной и той же цели, о Хвала Его Славе (BÍBLIA, 2011, Efésios 1.11-12). Так что вместе христиане образуют одно тело во Христе и индивидуально являются членами друг друга (BÍBLIA, 2011, Romanos 12.5), другими словами, это Христос для всех и всех во Христе, ведь есть один Бог, одна миссия (Его), одно видение и одна цель, Иисуса. Ему вся честь и слава, веками, аминь!

\section{ИСПОЛЬЗОВАННАЯ ЛИТЕРАТУРА}

ALLEN, Curtis. Como interpretar a Bíblia: princípios práticos para entender e aplicar a palavra de Deus. Tradução: Carlos Lopes. São Paulo: Vida Nova, 2012.

ALVES, Branca Moreira; PITANGUY, Jacqueline. O que é feminismo. São Paulo: Brasiliense, 1985. (Coleção Primeiros Passos).

BASKIN, Judith. Women in the Bible: changes in society affected attitudes toward women. Disponível em: https://www.myjewishlearning.com/article/women-in-thebible/. Acesso em: 13 mar. 2020.

BEAUVOIR, Simone. O segundo sexo. 2. ed. São Paulo: Difusão Europeia do Livro, 1970.

BÍBLIA. A Bíblia da Mulher. Leitura, devocional, estudo. 2. ed. Barueri, SP: Sociedade Bíblica do Brasil, 2011. 2176 p. Almeida Revista e Corrigida (ARC). (Português).

BIBLIATODO. Diário viver - comentário da Bíblia. Disponível em: https://www.bibliatodo.com/pt/comentarios-da-biblia/?v=PJFA\&co=diarioviver $\& \mathrm{I}=1+$ timoteo\&cap $=2$. Acesso em: 13 mar. 2020.

BRASIL. Ministério da Economia. Secretaria de Políticas Públicas e Emprego. Mulheres ocupam 43,8\% dos cargos de chefia no país. 08 mar. 2019. Disponível em: https://www.gov.br/economia/pt- 
br/assuntos/noticias/2019/03/mulheres-ocupam-43-8-dos-cargos-de-chefia-no-pais. Acesso em: 12 fev. 2020.

CHAMPLIN, Russell N. Comentário Bíblico do Novo Testamento: versículo por versículo. 3. ed. São Paulo: Milenium, 1982.

CUNDALL, Arthur E. Juízes. In: CUNDALL, Arthur E.; MORRIS, Leon. Juízes e Rute introdução e comentário. Tradução: Oswaldo Ramos. São Paulo, SP: Vida Nova, 1986.

JOSEFO, Flávio. História dos Hebreus: de Abraão à queda de Jerusalém. Tradução: Vicente Pedroso. 8. ed. Rio de Janeiro: Casa Publicadoras das Assembleias de Deus, 2004. (Obra Completa).

KELLER, Kathy. Jesus, justiça e papéis de gênero: mulheres no ministério. Tradução: João Guilherme Anjos. 1. ed. Rio de Janeiro: Thomas Nelson Brasil, 2019.

KOCHMANN, Sandra. O Lugar da Mulher no Judaísmo. Revista de Estudos da Religião, São Paulo, PUC-SP, n. 2, p. 35-45, 2005. Disponível em: https://www.pucsp.br/rever/rv2_2005/p_kochmann.pdf. Acesso em: 09 fev. 2020.

LIMA, Daniel Barros; MELLO, Adriana Girão da Silva. A mulher e os desafios na conquista do pastorado: Um estudo de caso em uma igreja evangélica Assembleia de Deus na cidade de Manaus. Coisas do Gênero, Revista de estudos feministas em gênero e religião. v. 2, n. 1. p. 119-134, Jan./Jul. 2016. Disponível em: http://www.est.com.br/periodicos/index.php/genero/article/view/2753. Acesso em: 10 fev. 2020.

LUCADO, Max. Dez mulheres da Bíblia: uma a uma elas mudaram o mundo. Tradução: Frank de Oliveira. 1. ed. Rio de Janeiro: Thomas Nelson Brasil, 2018. 
MACARTHUR, John. Doze Mulheres Extraordinariamente Comuns: como Deus moldou as mulheres da Bíblia e o que Ele quer fazer com você. Tradução: Maurício Bezerra Santos Silva. 1. ed. Rio de Janeiro: Thomas Nelson Brasil, 2019.

MERRIL, Eugene H. História de Israel no Antigo Testamento: o reino de sacerdotes que Deus colocou entre as nações. Tradução: Romell S. Carneiro. 3. ed. Rio de Janeiro: Casa Publicadoras das Assembleias de Deus, 1987.

NASCIMENTO, Cléia. Revista Seara, Rio de Janeiro, ano 41, n.16, mar. 1998.

PERROT, Michelle. Os excluídos da história: operários, mulheres e prisioneiros. 2. ed. Rio de Janeiro: Paz e Terra, 1992.

PFEIFFER, Charles F.; HARRISON, Everett F. Comentário Bíblico Moody: Josué a Cantares. v. 2. São Paulo, SP: Imprensa Batista Regular, 1985.

SHELDON, Charles M. Em seus passos o que faria Jesus? Tradução: Robinson Malkomes. São Paulo: Mundo Cristão, 2007.

SHPERBER, Daniel. Shlosha minhaguim mathimim, umekomam shel nashim beBeit Hakneset. In: SHILO, Margalit (org.). Lihiot Isha lehudia. Jerusalém: Ed. Urim, 2003. v. 2. p. 25-33.

TESSELER, Fani Averbuh. Vozes de mulheres: educação, universidade e trabalho nos anos 40 e 50 do Século XX. 2009. Tese. (Doutorado em Educação) Universidade Federal do Rio Grande do Sul. Porto Alegre, 2009. Disponível em: http://www.lume.ufrgs.br/bitstream/handle/10183/18381/000729544.pdf?sequence=1 . Acesso em: 20 mar. 2020.

TUPAN JÚNIOR, Galaor Linhares. Modelos de plantação de igrejas. Maringá, PR: Unicesumar, 2017.

VAUX, Roland de. Instituições de Israel no Antigo Testamento. São Paulo: Vida Nova, 2004.

RC: 104791

Доступно в: https://www.nucleodoconhecimento.com.br/богословие-ru/парадигмаженский-пастор 
WRIGHT, Nicholas Thomas. Paulo para todos: cartas pastorais. 1, 2 Timóteo e Tito. Tradução: Hilton Figueredo. Rio de Janeiro: Thomas Nelson Brasil, 2020.

\section{ПРИЛОЖЕНИЕ - СПРАВОЧНАЯ ИНФОРМАЦИЯ}

3. «Раввин Sandra Kochmann, выпускница Латиноамериканской раввинской семинарии «Marshall T. Meyer из Консервативного движения в Аргентине, а также в Организации и руководстве некоммерческими учреждениями, Университет Хебреа-Аргентина Бар-Илан. Участвовал в программе «Melton» по подготовке учителей еврейской диаспоры в Еврейском университете Иерусалима; с сентября 2003 года она является раввином Израильской религиозной ассоциации Рио-де-Жанейро (ARI), став первой женщиной, выполнившей эту задачу в Бразилия» (KOCHMANN, 2005, стр. 35).

Опубликовано: Ноябрь 2021 года.

Утвержден: Декабрь 2021 года. 